\title{
University Disciplinary Process: What's Fair, What's Due, and What You Don't Get
}

\author{
James M. Picozzi†
}

Public schools, the Supreme Court has repeatedly said, are vitally important "in the preparation of individuals for participation as citizens."1 Universities perform the vital function of teaching the "fundamental values necessary to the maintenance of a democratic political system."2

Within these training grounds for citizenship, school officials play a complex and virtually paradoxical role: they must maintain order among and authority over the same students to whom they must teach the values of individual liberty. Their actions, explained Justice Jackson, must not undercut the lesson:

Boards of Education . . . . have, of course, important, delicate, and highly discretionary functions, but none that they may not perform within the limits of the Bill of Rights. That they are educating the young for citizenship is reason for scrupulous protection of Constitutional freedoms of the individual, if we are not to strangle the free mind at its source and teach youth to discount important principles of our government as mere platitudes. ${ }^{3}$

Thus, the Supreme Court vigorously defended the constitutional rights of students in public schools, even during the difficult 1960's. ${ }^{4}$ That protec-

$\dagger$ As a former defendant in a student disciplinary case, $I$ have strong feelings about many of the issues discussed in this Note. I do not deny a degree of bias, but I believe that bias to be more than outweighed by the special insight my experience has given me into these issues. I ask only that the reader consider the ideas on their merits.

Cases involving the University of Michigan receive lengthy treatment in this Note, not because I harbor a special animosity towards it, but because it has produced three significant cases in the area: Regents of the Univ. of Mich. v. Ewing, 106 S. Ct. 507 (1985), because it is the most recent pronouncement by the Supreme Court on the rights of students at public universities; Crook v. Baker, 584 F.Supp. 1531 (E.D. Mich. 1984), because of the unusual detail in which Judge Taylor describes the case history; and Picozzi v. Sandalow, 623 F. Supp. 1571 (E.D. Mich. 1986), because it raises many as yet unresolved issues and because I have special knowledge of many of the "off-record" facts.

1. Ambach v. Norwick, 441 U.S. 68, 76 (1979); accord Board of Educ. v. Pico, 457 U.S. 853, 864 (1982).

2. Ambach, 441 U.S. at 77.

3. West Virginia Bd. of Educ. v. Barnette, 319 U.S. 624, 637 (1943).

4. See, e.g., Tinker v. Des Moines School Dist., 393 U.S. 503 (1968) (suspension of three public high school students for wearing black armbands in protest against United States involvement in Vietnam held unconstitutional). For many years thereafter, no student rights opinion by any court 
tion reached its apogee in Goss v. Lopez, ${ }^{5}$ a case involving a ten-day suspension from a public high school. "At the very minimum," wrote Justice White for the majority, "students facing suspension and the consequent interference with a protected property interest must be given some kind of notice and afforded some kind of hearing." Justice White went on to outline the necessary procedure for a ten-day suspension from public high school, but was careful to explain that the procedure was tailored to the specific facts in Goss. A longer suspension or an expulsion, he wrote, "may require more formal procedures."

To this day, however, the Supreme Court has never specified what those more formal procedures should be or when they should be required. ${ }^{8}$ Indeed, far from filling in the interstices of Goss, the Court instead has carefully avoided any further definition of the scope or extent of due process protections in university disciplinary actions. Twice, for instance, the Court has declined to reach the question of whether students at public universities have a property or liberty interest in their educations. ${ }^{9}$ Such a holding would have triggered the due process requirements of the Fourteenth Amendment and placed public university students squarely within the dictates of Goss. ${ }^{10}$ In both cases, though, the Supreme Court merely "assumed" the existence of a property or liberty interest for the

was complete without quoting Justice Fortas's statement that students do not "shed their constitutional rights to freedom of speech or expression at the schoolhouse gate." Id. at 506.

5. 419 U.S. 565 (1975).

6. 419 U.S. at 579 . The Goss opinion did specify that notice must inform the student of "what he is accused of doing and what the basis of the accusation is," id. at 582, and that the hearing must provide the student with "an opportunity to present his side of the story," id. at 581 . Moreover, by definition, a due process hearing requires an impartial decisionmaker. See infra note 43. Since Goss v. Lopez, it has been well-settled that these bare elements of process are due a student before an expulsion or any suspension that is not de minimis.

7. Id. at 584 .

8. Additionally, Goss held that "as a general rule notice and hearing should precede removal of the student from school," but allowed that the student might be removed first where his "presence poses a continuing danger to persons or property or an ongoing threat of disrupting the academic process." Id. at 582. Again, however, the Court has never specified what dangers justify immediate suspension.

9. Regents of the Univ. of Mich. v. Ewing, 106 S. Ct. 507 (1985); Board of Curators of the Univ. of Mo. v. Horowitz, 435 U.S. 78 (1978); see infra note 11.

10. Although some different values are at work at the high school level than at the university level, similar constitutional theories apply to both. It does not matter that attendance at high school is required by state law, whereas attendance at a university may be deemed a privilege. Whether a benefit is characterized as a "right" or a "privilege" has no constitutional significance. See Graham v. Richardson, 403 U.S. 365, 374 (1971). The only relevant inquiry is whether the student's interest in remaining in school falls "within the contemplation of the 'liberty or property' language of the Fourteenth Amendment." Morrissey v. Brewer, 408 U.S. 471, 481 (1972). If it does, then process is due a student before dismissal and the dictates of Goss apply. See infra Section I.

The amount of process due increases according to the interest the student has at stake. Mathews v. Eldridge, 424 U.S. 319 (1976). As dismissal from a university implicates a much greater interest than dismissal from a high school, not only should the degree of process increase, but so should the degree of concern over erroneous deprivations. See infra Sections I and IV. 
purposes of argument ${ }^{11}$ and then proceeded to decide each case on narrower grounds.

While the Supreme Court equivocated, the lack of a national procedural standard spawned litigation-as universities were free to call any type of teacher-student meeting a hearing, and students were forced to bring suit to obtain fair procedure. Ruling on these cases, however, the lower federal courts did not equivocate. Consistently, they found public university students do hold property and liberty interests in their educations and, consequently, all applied the minimal Goss standard of "some kind of a hearing" before expulsion. ${ }^{12}$ Yet, without a ruling by the Supreme Court specifying how much process a student was due, the district courts applied Goss unevenly.

Recently, the Supreme Court has become active again, deciding several new cases involving the application of constitutional standards to public schools. ${ }^{13}$ Rather than press ahead to fill the gaps left by Goss $v$. Lopez, though, the Court has instead begun a retreat from its former strong defense of students' rights. The question has become how much further the Gourt will go in restricting students' rights and, more importantly to the subject of this Note, how far will those restrictions be extended to include students at public universities? The face of public education has changed and, as the Supreme Court itself has raised the question time and again, one also wonders what a reduction of student rights will teach young citizens about the democratic political system. ${ }^{14}$

This Note explores the dangers in allowing public university officials unbridled authority to suspend or expel students for disciplinary reasons. ${ }^{15}$ Section I examines the student's interests in not being arbitrarily

11. Ewing, $106 \mathrm{~S}$. Ct. at 512 (even if student had property interest giving rise to substantive due process right against arbitrary state action, record of student's academic expulsion disclosed no arbitrary action); Horowitz, 435 U.S. at 91-92 (even if academic expulsion could be reviewed under arbitrary and capricious standard, student made no showing of arbitrariness and capriciousness).

12. See infra Section I.

13. Bethel School Dist. v. Fraser, 106 S. Ct. 3159 (1986) (upholding suspension of high school student for student election speech that was sexually suggestive, but not explicit); New Jersey $v$. T.L.O., 469 U.S. 325 (1985) ("reasonable grounds," not "probable cause," is standard for in-school search of student's locker, belongings, or person).

14. In striking down the arbitrary expulsion of several students from the Alabama State College in 1961, the United States Court of Appeals for the Fifth Circuit wrote the following:

In the disciplining of college students there are no considerations of immediate danger to the public, or of peril to the national security, which should prevent the [Alabama State Board of Education] from exercising at least the fundamental principles of fairness by giving the accused students notice of the charges and an opportunity to be heard in their own defense. Indeed, the example set by the Board in failing so to do, if not corrected by the courts, can well break the spirits of the expelled students and of others familiar with the injustice, and do inestimable harm to their education.

Dixon v. Alabama State Bd. of Educ,, 294 F.2d 150, 157 (5th Cir. 1961).

15. The Supreme Court distinguishes between academic and disciplinary dismissals, deferring in the former case to the professional judgment of educators. Justice Rehnquist explained: 
dismissed from a university and demonstrates how those interests rise to the level of "property and liberty" within the contemplation of the Fourteenth Amendment. Section II examines the private interests of individual university administrators-as opposed to the interests of the institutions themselves-and how those interests can conflict with the legitimate interests of the student in disciplinary situations. Section III examines how the administrator's private interests infect the disciplinary process, even when the interested administrator is excluded. Section IV explores the difficulties a student can face when a university uses unfair procedures. Section $\mathrm{V}$ suggests a framework for disciplinary procedures which would balance the student's interests against the university's legitimate interests in maintaining order.

\section{The Private Interest: What the Student Stands To Lose}

In determining what rights a student has against arbitrary dismissal, one must first ask whether the nature of the student's interest falls "within the contemplation of the 'liberty or property' language of the Fourteenth Amendment."16 If it does, then process is due the student before that interest can be extinguished. ${ }^{17}$ Despite the Supreme Court's hesitancy, ${ }^{18}$ lower federal courts have consistently held that dismissal from a public university implicates property and liberty interests. ${ }^{19}$ While the

Like the decision of an individual professor as to the proper grade for a student in his course, the determination whether to dismiss a student for academic reasons requires an expert evaluation of cumulative information and is not readily adapted to the procedural tools of judicial or administrative decisionmaking.

Board of Curators of the Univ. of Mo. v. Horowitz, 435 U.S. 78, 90 (1978). Consequently, the Court ruled that it would not require as much procedure in cases of academic dismissal as it would in cases of disciplinary dismissal. Id. at 86. Recently, in Regents of the Univ. of Mich. v. Ewing, 106 S. Ct. 507,514 (1985), the Court reaffirmed that distinction.

16. Morrissey v. Brewer, 408 U.S. 471, 481 (1972).

17. How much process depends upon the balance of three factors identified by the Supreme Court in Mathews v. Eldridge, 424 U.S. 319, 335 (1976). The first factor is the private interest to be affected-here, the student's interest in continuing his education. The second factor is the risk of erroneous deprivation under the present procedures and the probable value of additional procedures. The third and final factor is the government's interest, including the function of the agency involved and the burden of providing additional procedures. If the private interest outweighs the government interest, and additional procedures would avoid mistakes, then greater process is due.

At the outset, one must acknowledge the legitimate interests of the government, in the form of the university, in maintaining discipline. See infra Section V. This Note assumes the legitimate weight of the university's interests as a backdrop to its discussions and, instead, goes on to explore two other points about the Mathews balance. First, one must be careful to separate the private interests of university officials from the legitimate interests of the university itself. Currently, the former are allowed to tilt the balance, making erroneous deprivations all but inevitable. Second, even when considering the full weight of the university's legitimate interests, the countervailing weight of the student's interests are so overwhelming that, under the Mathews balance, much more process is due students than they currently receive.

18. See supra notes $9-11$ and accompanying text.

19. See, e.g., Stoller v. College of Medicine, 562 F. Supp. 403, 412 (M.D. Pa. 1983), affd without opinion, 727 F.2d 1101 (3rd Cir. 1984); Greenhill v. Bailey, 519 F.2d 5, 7 (8th Gir. 1975); 
reasoning of the lower courts is conclusory, ${ }^{20}$ such a finding seems inescapable under the Supreme Court's own decisions.

\section{A. A Student's Property Interest}

The Fourteenth Amendment does not create interests in property. Rather, property interests "are created and their dimensions are defined by existing rules or understandings that stem from an independent source such as state law-rules or understandings that secure certain benefits." In Goss v. Lopez, for example, the Court found that a property interest in attending school had been created by an Ohio statute which required attendance for persons between the ages of six and eighteen. ${ }^{22}$ In the employment context, the Court has found property interests in continued employment to have been created by term contracts, ${ }^{23}$ tenure, ${ }^{24}$ and even implied promises. ${ }^{25}$ Indeed, in Board of Regents v. Roth, ${ }^{26}$ the Court explained that any basis for legitimate reliance may create a property interest:

To have a property interest in a benefit, a person clearly must have more than an abstract need or desire for it. He must have more than a unilateral expectation of it. He must, instead, have a legitimate claim of entitlement to it. It is a purpose of the ancient institution of property to protect those claims upon which people rely in their daily lives, reliance that must not be arbitrarily undermined. ${ }^{27}$

Gaspar v. Bruton, 513 F.2d 843, 850 (10th Cir. 1975); Grook v. Baker, 584 F. Supp. 1531, 1554 (E.D. Mich. 1984); Hart v. Ferris State College, 557 F. Supp. 1379, 1382 (W.D. Mich. 1983); Hall v. University of Minn., 530 F. Supp. 104, 107 (D. Minn. 1982); Ross v. Pennsylvania State Univ., 445 F. Supp. 147, 152 (M.D. Pa. 1977).

20. See, e.g., Gaspar v. Bruton, 513 F.2d 843, 850 (10th Cir. 1975), where the court wrote: We have no difficulty in concluding that in light of Goss, . . . where the Supreme Court recognized a property right in public school students that certainly such a right must be recognized to have vested with [the university student], and the more prominently so in that she paid a specific, separate fee for enrollment and attendance.

See also Hart v. Ferris State College, 557 F. Supp. 1379, 1382 (W.D. Mich. 1983) ("It is undisputed that the threat of suspension or expulsion implicates plaintiff's property and liberty interests in public education and reputation.").

21. Board of Regents v. Roth, 408 U.S. 564, 577 (1972).

22. 419 U.S. $565,573-74$ (1975).

23. Wieman v. Updegraff, 344 U.S. 183 (1952).

24. Slochower v. Board of Educ., 350 U.S. 551 (1956).

25. Connell v. Higginbotham, 403 U.S. 207 (1971).

26. 408 U.S. 564 (1972).

27. Id. at 576-77. Roth was a teacher at a state college with a one-year contract. At the end of the contract year, he was informed he would not be rehired. Roth brought suit, claiming a property interest in continued employment. The Supreme Court ruled he did not have a property interest because his employment contract had a specific termination date with no provision for renewal and, thus, Roth had no legitimate reliance in employment past the one year. Unlike a student who must explain why he leaves a university before graduating, see infra notes $38-40$, the termination date in Roth's contract was its own explanation. Indeed, as there was never a mutual understanding that Roth would continue past the termination date, his situation is analogous to the student who does 
Any university student in good academic standing has more than a "unilateral expectation" that, upon completion of the required course work, he ${ }^{28}$ will receive his degree. By accepting tuition and providing instruction in return, the university forms a contract with the student ${ }^{29}$ and gives substance to his expectation of graduation..$^{30}$ If the expectation were "unilateral," the university would not have enrolled the student at all.

\section{B. A Student's Liberty Interest}

In Wisconsin v. Constantineau, the Supreme Court stated that liberty interests subject to the protection of due process are present "[w]here a person's good name, reputation, honor or integrity is at stake because of what the goverment is doing to him."'31 Thus, in Constantineau, the Court held that it was unconstitutional for government officials to post the names of habitual drunkards in retail liquor outlets without first providing a hearing to those whose names it sought to post. ${ }^{32}$ Increasingly, however, the Supreme Court has been reluctant to find these interests. In Paul v. Davis, ${ }^{33}$ it held that not every defamation infringes sufficiently upon liberty interests to trigger procedural protection. Rather, stigma must be accompanied by the deprivation of a right previously held under state law, or result in some other alteration of legal status, such as employment. ${ }^{34}$ Using Goss $v$. Lopez as an example, the Paul Court explained that the stigma of the students' suspension was accompanied by deprivation of their property right under state law to attend school and, thus, a liberty interest was implicated as well. ${ }^{35}$ More interestingly, though, the Paul Gourt explained its decision in Wisconsin v. Constan-

graduate.

28. All masculine forms appearing in nonfactual statements throughout this Note are used in their generic sense.

29. See, e.g., Behrend v. State, 55 Ohio App. 2d 135, 139, 379 N.E.2d 617, 620 (1979); Anderson v. Regents of the Univ. of Cal., 22 Cal. App. 3d 763, 769, 99 Cal. Rptr. 531, 535, cert. denied, 409 U.S. 1006 (1972).

30 In a companion case to Roth, the Court further explained that a property interest will be found "if there are such rules or mutually explicit understandings that support [a] claim of entitlement." Perry v. Sindermann, 408 U.S. 593, 601 (1971) (teacher at state college could show legitimate claim of entitlement to continued employment through existence of rules and understandings fostered by state officials); of. Nordin, The Contract To Educate: Toward a More Workable Theory of the Student-University Relationship, 8 J. ColLEGE \& U.L. 141 (1980-1982) (arguing courts should find implied contract between university and student, and should look to provisions of college bulletins and academic traditions as some evidence of parties' reasonable expectations).

31. 400 U.S. 433,437 (1971).

32. Id.; see also Joint Anti-Fascist Refugee Comm. v. McGrath, 341 U.S. 123 (1951) (United States Attorney General's designation, without notice or hearing, of three charitable organizations as "Communist" held actionable).

33. 424 U.S. 693 (1976).

34. 424 U.S. at $708-09$.

35. Id. at 710 . 
tinea ${ }^{36}$ by saying that the alteration in Constantineau's legal status was "the right to purchase or obtain liquor in common with the rest of the citizenry." 37

Dismissal from a university alters the student's legal status in many ways. If, for example, the student does hold a property interest in his education, then the Paul opinion's example of Goss v. Lopez makes clear that a student's liberty interest would be infringed as well. Similarly, if a contract does exist between the university and a student, then again the Paul opinion's example of terminating employment makes clear that breaking the contract through dismissal alters a student's legal status.

The most significant alteration of an expelled student's status, though, is his inability to re-enroll at another university. A subsequent university to which a student may apply always knows of the reasons for his prior dismissal. ${ }^{38}$ Unlike an employee at will who may leave a position for a number of reasons, ${ }^{38}$ educational institutions presume that, absent some academic or behavioral failure, a student continues at a university until he earns his degree. If he leaves without having earned his degree, the student must make an affirmative showing to any subsequent university to which he applies that he left the original university in "good standing" (i.e., that he did not fail academically and is free to re-enroll). ${ }^{40}$ Conse-

36. 400 U.S. 433 (1971); see supra note 31 .

37. 424 U.S. at 708.

38. american Association of Collegiate Registrars and Admissions Officers, A Guide to an Adequate Permanent Record and Transcript 11 (1971) ("There are three major reasons for a student's leaving an institution prior to completion of his degree: (1) personal; (2) academic; (3) disciplinary."). Any institution to which a student may transfer will require an affirmative showing of which of these reasons caused the student to leave his prior institution. See infra note 40.

39. Cf. Bishop v. Wood, 426 U.S. 341 (1976). Less than three months after Paul, the Court in Bishop suggested that procedural protection would be triggered even for an employee at will if his termination was accompanied by publication of the reasons for termination, as there was a danger potential subsequent employers would learn of those reasons. Id. at 348; see also Doe v. United States Dept. of Justice, 753 F.2d 1092 (D.C. Cir. 1985) (discharge from public employment for publicly disclosed, defamatory reasons infringes on protected liberty interest); Old Dominion Dairy Products v. Secretary of Defense, 631 F.2d 953, 962-63 (D.C. Cir. 1980) (although no protected property interest in government contracts, " 'stigmatizing' governmental defamation having an immediate and tangible effect" on contractor's business infringes upon protected liberty interest); Greenhill v. Baily, 519 F.2d 5, 8 (8th Cir. 1975) (dismissal from medical school accompanied by notification to Liaison Committee of Association of American Medical Colleges that student lacked "intellectual ability" infringed protected liberty interest).

40. See Anerican Association of Collegiate Registrars and Admissions Officers, Academic Record and Transcript Guide 21 (1984 rev.) (defining "good standing" as "eligible to continue at or return to an institution"). A student commonly does so not just through the use of a transcript from the first university, but also through a document commonly referred to as a letter of good standing. Without such a letter, most universities will not consider the student's application on its merits at all; in certain graduate-professional fields, such as law and medicine, no schools will accept a student who cannot produce such a letter. See Picozzi v. Sandalow, 623 F. Supp. 1571, 1576 (E.D. Mich. 1986). Picozzi illustrates how little courts have explored the implications of university expulsion. No other court had ever defined what a letter of good standing was, let alone the letter's constitutional significance. The defendant Terrance Sandalow, Dean of the Michigan Law School, 


\section{University Disciplinary Process}

quently, to be dismissed from one university-in most cases and, in the highest circles of academia, in all cases-means the student can never again be a candidate for any degree. Unlike an employee at will who has been discharged, the disciplined student cannot simply return to his original position before enrollment. The employee may find a new job; the student cannot find a new university.

A more telling comparison, though, may be to Wisconsin v. Constantineau. If it altered Constantineau's legal status not to be free to purchase liquor with the rest of the citizenry-and, again, the Paul opinion says that it did-then a fortiori for a student no longer to be free to have his application to a university considered on the merits, which implicates a much broader interest, must also alter a legal status.

The economic wound inflicted by dismissal remains with a student for the rest of his life, ${ }^{41}$ but often the wound goes deeper. In notorious cases, universities are wont to publicize apprehensions of offending students in order to placate the university community, irrespective of the emotional distress to the student or the irreparable harm to the student's reputation. ${ }^{42}$

claimed a letter of good standing was analogous to a letter of recommendation and, thus, a student in good standing did not have an unqualified right to receive one. Rather, providing a letter lay in the Dean's absolute discretion. The District Court rejected Sandalow's argument. Id. at 1577.

Even at an institution that would not require a letter of good standing, a transfer applicant would likely be required to inform the school if he has been involved in any disciplinary procedures at his first institution, whether the student was found guilty of any infractions or not. The 1971 revision of the ACADEMIC RECORD AND TRANSCRIPT GuIDE listed as an "essential" item of a student's permanent record any suspension or expulsion of a student for disciplinary reasons. AMERICAN Association of Collegiate Registrars and Admissions Officers, supra note 38, at 5-6. Although the 1984 revision dropped the student's disciplinary history as an "essential" item, many universities maintain the practice. Simply by omitting any statement of good standing or a disciplinary history, therefore, the student's first university can signal any second university to which he may apply that something is amiss and, consequently, provoke an inquiry.

The understanding among universities, that one will not accept a student in transfer unless his prior institution certifies that student as being in good standing, should be distinguished from the mutual understanding in Perry v. Sindermann, 408 U.S. 593, 601 (1971). A student's claim of entitlement to a letter of good standing derives from his relationship with his original institution; the mutual understanding among universities only demonstrates the student's injury in fact. In contrast, the mutual understanding in Perry actually created the teacher's claim of entitlement to continued employment. See supra note 30.

41. The 1980 Census showed that men with four years of college earn an average of $38 \%$ more than those with only a high school diploma in the 25-34 year old age bracket; the difference rises to almost $64 \%$ by the time men reach age 65 . Women with four years of college earn an average of $21 \%$ more than those with only a high school diploma in the 25-34 year old age bracket; the difference rises to almost $36 \%$ by the time women reach age 65 . UNITED STATES BUREAU OF THE CENSUS, EArnings by Occupation and Education, Series PC80-28B, 1 (May 1984).

Moreover, the difference in wages for those with and without a college education is increasing. See United States Bureau of the Census, Special Demographic analysis, Education in the UnITEd STATES: 1940-1983, SERIES CDS-85-1 40-41 (July 1985).

42. In the fall of 1983 , there were more than 40 arson fires started on the campus of the University of Massachusetts. Most of these were small, mostly started in trash cans, bathrooms, and on bulletin boards. The problem received national attention, however. In December, the University charged that senior Yvette Henry had started all of the fires, based upon its suspicion that she had set 
When one tallies the potential harm to a student-lifetime impairment of economic mobility, lifetime prohibition from higher education, and public belief that one has done something wrong, perhaps even committed a felony - the penalty for dismissal from a university for disciplinary reasons resembles the suspended sentence a felon might receive in a criminal court.

\section{The Competing Interests: Unfair Influences on the DECISIONMAKER}

Protection against wrongful deprivation of a student's property and liberty interests requires an impartial decisionmaker ${ }^{43}$ and, thus, turns upon the integrity of the individual school administrator. ${ }^{44}$ The courts presume good faith on the part of school administrators-but why they do so is unclear.

Judicial deference may, in part, stem from the paternalistic attitude that is explicit in the Supreme Court's decisions concerning secondary schools. ${ }^{45}$ Deference also stems from the notion that universities enjoy a

just one on another student's desk. The University accusation caused her to be criminally charged as well. Henry was arrested, held overnight in jail, suspended and barred from the university, and fired from her job as a resident assistant. (Eventually, she was allowed back on campus in the presence of an escort.) Additionally, the University announced it had caught the arsonist-an announcement which received national attention. However, Yvette Henry had not set any of the fires. All charges against her were dropped due to lack of evidence some three weeks later. Boston Globe, May 8, 1984, at 15 , col. 1. Henry's experience illustrates the harm which university administrators-even wellintentioned university administrators-can cause due to a lack of expertise in the areas of investigation and procedural fairness.

Additionally, it shows how pre-hearing publication may place a university in the embarassing situation of having to recant, and even apologize for, its original position-thus creating another potential bias. Cf. Cinderella Career and Finishing Schools, Inc. v. FTC, 425 F.2d 583, 590 (D.C. Cir. 1970) (denial of due process for FTC Commissioner to make speech giving appearance that case was prejudged, as it has effect of "entrenching a Commissioner in a position which he has publicly stated, making it difficult, if not impossible, for him to reach a different conclusion in the event he deems it necessary to do so after consideration of the record.").

43. In Marshall v. Jerrico, Inc., 446 U.S. 238 (1980), the Supreme Court explained why the due process clause entitles a person to an impartial decisionmaker:

This requirement of neutrality in adjudicative proceedings safeguards the two central concerns of procedural due process, the prevention of unjustified or mistaken deprivations and the promotion of participation and dialogue by affected individuals in the decisionmaking process.

The neutrality requirement helps to guarantee that life, liberty, or property will not be taken on the basis of an erroneous or distorted perception of the facts or the law. At the same time, it preserves both the appearance and reality of fairness, "generating the feeling, so important to a popular government, that justice has been done."

Id. at 242 (citations omitted). For more in-depth commentary on the importance of an impartial decisionmaker, see Friendly, Some Kind of Hearing, 123 U. PA. L. REv. 1267 (1975); Redish \& Marshall, Adjudicatory Independence and the Values of Procedural Due Process, 95 YALE L.J. 455 (1986).

44. "The contention that the combination of investigative and adjudicative functions necessarily creates an unconstitutional risk or bias in administrative adjudication . . . . must overcome a presumption of honesty and integrity in those serving as adjudicators . . . "Withrow v. Larkin, 421 U.S. 35, 47 (1975).

45. See, e.g., Bethel School Dist. No. 403 v. Fraser, 106 S. Ct. 3159, 3165 (1986) ("Consciously 


\section{University Disciplinary Process}

special collegial environment. ${ }^{48}$ Yet, once a student has been charged with an offense serious enough to lead to expulsion, it is unrealistic to think that the relationship between administrator and student does not become an adversarial one. Finally, deference stems from the belief, expressed in Board of Curators of the University of Missouri $v$. Horowitz ${ }^{47}$ and Regents of the University of Michigan $v$. Ewing, ${ }^{48}$ that teachers are the education experts and, therefore, a court should not replace a teacher's academic judgments with its own. Disciplinary judgments are not academic judgments, however, and teaching ability has little to do with competence to prosecute a dormitory rapist. Indeed, questions of fair procedure are the specialty of courts and it makes no sense for them, in a disciplinary setting, to defer to school administrators. Moreover, even if there were some correlation between teaching and procedural competence, the school administrator who does prosecute a dormitory rapist may not be a teacher at all.".

Individual university administrators are allowed to fill many roles, a number of which may conflict. For example, they fill the roles of both fund-raiser and disciplinary adjudicator, although refusing to punish an unpopularly vocal student might not be good public relations. Perhaps more telling, though, is a comparison to the criminal justice system. A university administrator may-and frequently does-fill all the roles of police (enforcing rules and identifying those who break them), prosecutor (deciding who should be charged for breaking the rules), judge (agreeing who should be charged for breaking the rules and deciding on fact-finding procedures) and jury (deciding if the individual is guilty as charged). By melding all of these roles in one person, these functions no longer check

or otherwise, teachers . . . demonstrate the appropriate form of civil discourse and political expression by their conduct and deportment in and out of class. Inescapably, like parents, they are role models.").

46. See, e.g., New Jersey v. T.L.O., 469 U.S. 325, 349-50 (1985) (Powell, J., concurring):

The special relationship between teacher and student also distinguishes the setting within which schoolchildren operate. Law enforcement officers function as adversaries of criminal suspects. These officers have the responsibility to investigate criminal activity, to locate and arrest those who violate our laws, and to facilitate the charging and bringing of such persons to trial. Rarely does this type of adversarial relationship exist between school authorities and pupils. Instead, there is a commonality of interests between teachers and their pupils.

47. 435 U.S. 78 (1978).

48. 106 S. Ct. 507 (1985).

49. See, e.g., C. KerR, The USES OF THE UNIVERSTrY 28 (1972) ("As the institution becomes larger, administration becomes more formalized and separated as a distinct function."); id. at 42 ("Teaching is less central than it once was. . . . [giving] rise to what has been called the "nonteacher'- 'the higher a man's standing, the less he has to do with students." "). 
one another. ${ }^{50}$ Any administrator who initially decides a student should be charged naturally has a predisposition to find him guilty of that charge. ${ }^{51}$

Although in other cases a melding of functions alone has not been held to violate due process, ${ }^{62}$ the Court has recognized that such a melding creates a "substantial" constitutional issue requiring different solutions in different contexts. ${ }^{53}$ Moreover, in no context has the Supreme Court ever been willing to ignore specific bias. ${ }^{54}$

Since Dr. Bonham's Case, ${ }^{55}$ it has been axiomatic that no man may be

50. For example, consider the many hats worn by Roderick Daane, General Counsel of the University of Michigan, in Crook v. Baker, 584 F. Supp. 1531 (E.D. Mich. 1984). The University sought to rescind Crook's Master of Science degree some two years after his graduation. It charged Crook exactly as if he were still enrolled as a student. Id. at 1538-40. Daane, at various points in the process, acted as a supposedly neutral General Counsel in establishing the hearing's procedural rules, id. at 1536, 1539, 1545, as counsel for the Geology Department in its prosecution, as legal advisor to the Chairman of the panel deciding the case, as General Counsel to the Executive Board of the Graduate School when it heard the case on appeal, and finally as legal advisor to the University's Vice President when he presented the case on final appeal to the Board of Regents. Id. at 1541. Daane would selectively type in "Office of the General Counsel" at the top of his correspondence, depending on which role he wanted to play. Id. at 1552. At one point he dictated the hearing's procedural rules to Crook's attorney and stated that he had established them from his impartial role as General Counsel-yet, at trial, he claimed that the failure of opposing counsel to object to the rules constituted a "stipulation." Id. at 1542.

The Federal District Court wrote the following concerning Daane's conduct:

It appears that Daane, once committed to the success of this adventure, subverted many other of the University's more compelling interests and paramount values to its accomplishment. As the charges advanced, he assumed the role most advantageous to their success, and was far less than candid with those others who were drawn into the problem and with this court.

Id. at 1551 .

51. See In re Murchison, 349 U.S. 133 (1955); infra note 64.

52. See Withrow v. Larkin, 421 U.S. 35 (1975) (no violation of due process for medical committee which investigated allegations of physician's misconduct and recommended prosecution also to adjudicate charges); Richardson v. Perales, 402 U.S. 389, 410 (1971) (demand that administrative agencies separate functions "assumes too much and would bring down too many procedures designed, and working well, for a governmental structure of great and growing complexity").

53. Withrow v. Larkin, 421 U.S. at 51 :

The issue is substantial, it is not new, and legislators and others concerned with the operations of administrative agencies have given much attention to whether and to what extent distinctive administrative functions should be performed by the same persons. No single answer has been reached. Indeed, the growth, variety, and complexity of the administrative processes have made any one solution highly unlikely.

The one specific example Withrow gave of how the problem has been addressed was Congress' adoption of the Administrative Procedure Act, 5 U.S.C.A. § 554(d) (West 1977), which provides generally that no employee engaged in investigating or prosecuting may also participate or advise in the adjudicating function. 421 U.S. at 52.

54. In Withrow v. Larkin, 421 U.S. at 47 , the Court stated:

In pursuit of [an unbiased decisionmaker], various situations have been identified in which experience teaches that the probability of actual bias on the part of the judge or decisionmaker is too high to be constitutionally tolerable. Among these cases are those in which the adjudicator has a pecuniary interest in the outcome and in which he has been the target of personal abuse or criticism from the party before him.

See also Hastings v. Judicial Conference of the United States, 770 F.2d 1093, 1110 (D.C. Cir. 1985) ("II]n Withrow v. Larkin the Supreme Court held that the mere combination of investigative and adjudicative functions does not automatically create a presumption of bias. The Withrow Court, however, assumed that judicial review of actual bias was available." (citation omitted)).

55: 77 Eng. Rep. 646, 8 Coke 114a (C.P. 1610). 
a judge in a case in which he has an interest in the outcome and, indeed, that the mere likelihood of actual influence has been enough to disqualify a judge. ${ }^{5 B}$ Of the potential biases to an adjudicator, financial interest is recognized as the greatest temptation..$^{87}$ Yet, the law currently tolerates a combination of potential biases, especially financial biases, on the part of university administrators that are not tolerated in any other context.

As higher education has undeniably become big business, ${ }^{58}$ any decision by a university administrator may now implicate a pecuniary interest sufficient to meet Withrow v. Larkin's test of specific bias. University administrators must be concerned with fundraising and, ultimately, with public relations. ${ }^{58}$ Frequently the ability of an institution to survive, let alone prosper, may depend upon its public image. ${ }^{60}$ Moreover, a university ad-

56. Tumey v. Ohio, 273 U.S. 510 (1927). Tumey had been convicted of unlawful possession of intoxicating liquor by the town's Judge-Mayor. An Ohio statute provided that in the case of a conviction, the Judge-Mayor would receive his costs from the imposed fine. In a unanimous decision, the Supreme Court ruled the arrangement violated the due process clause of the Fourteenth Amendment. Significantly, the Court did not find that the Judge-Mayor was biased. Rather, it was enough that "possible temptation" existed and that the arrangement appeared unfair. Id. at 532; cf. In re Murchison, 349 U.S. 133, 136 (1955) ("[O]ur system of law has always endeavored to prevent even the probability of unfairness.").

Moreover, a financial stake need not be as direct or positive as that in Tumey. See Ward v. Village of Monroeville, 409 U.S. 57 (1972) (trial of traffic offenses before mayor of village that received half its revenues from mayor's court violates due process clause).

57. See, e.g., Aetna Life Ins. Co. v. Lavoie, 106 S. Ct. 1580 (1986) (violation of due process for state supreme court justice to participate in proceeding against insurer, where justice had filed similar action against insurer, and decision enhanced legal status and settlement value of justice's own case); Gibson v. Berryhill, 411 U.S. 564 (1973) (denial of due process for state optometry board, consisting solely of optometrists in private practice for their own account, to adjudicate license revocation hearings against optometrists working through corporations, as effect of revocation would redound to personal pecuniary interest of board members).

58. In the academic year $1984-85$, corporations alone gave colleges and universities almost $\$ 1.6$ billion. Total voluntary support exceeded $\$ 6.3$ billion, up $12.9 \%$ from $1983-84$ and $66.3 \%$ from 1979-80. The Council for Finencial Aid to Education Newsletter, May 1986.

Even when broken down by individual schools, the figures are staggering. For the academic year $1984-85$, voluntary support to UCLA totalled $\$ 62,591,722$, to the University of Minnesota $\$ 66,203,892$, and to the University of Illinois $\$ 70,698,392$. Id.

59. See State Colleges Seeking Share of Philanthropic Pie, N.Y. Times, July 29, 1986, at A1, col. 4 (describing competition among universities, and their officials, seeking to raise funds of hundreds of millions of dollars for individual institutions).

60. "You can't run a first-class public university any more on public money alone," says Robert H. Huttenback, Chancellor of the University of California at Santa Barbara. Id.

In 1984, a commission organized by the Association of Governing Boards of Universities and Colleges specifically recognized the need to present a positive public image-to be achieved through greater autonomy in resolving internal disputes-and successful fundraising. The so-called "Kerr Commission" report stated that "new constraints, outside the control of higher education, bind the [university] presidents as never before in their freedom of action." See Association of Governing Boards of Colleges and Universities, Presidents Make a Difference: Strengthening Leadership in Colleges and Universities xii (1984). The Commission concluded that university presidents had to be given greater autonomy (or, as the Commission self-consciously put it, a greater "share" of the "governance") in order to attain certain necessary goals. Id. at 100 . The goal it listed first was the "attraction of maximum financial resources to the institution," followed closely by the "persuasive representation of the institution to concerned external publics" and the "resolution of internal conflicts and misunderstandings." Id. at 100-101. The majority of the report's data came from interviews with more than 800 current or former university presidents, deans, chancellors, and 
ministrator's retaining his position may depend upon his ability to maintain the appearance of a tranquil campus to encourage prospective donors. ${ }^{61}$ Consequently, faced with a student disturbance, a university administrator may not be thinking as a teacher or even an adjudicator; he is more likely thinking in utilitarian terms about what is best for the institution at the expense of individual justice, ${ }^{62}$ or just as a bureaucrat protecting his job.

administrators. Presumably, the goals the report identified were their goals.

61. While no statistics can be compiled to show what correlation exists between insufficient fundraising and university administrators losing their positions, the Kerr Commission report makes clear both that fundraising has become an increasingly important concern of high-ranking university officials while, incidentally, the average term of a university president is shrinking. Id. at ix.

The comparison to the Administrative Procedure Act, utilized by the Court in Withrow v. Larkin, 421 U.S. 35, 52 (1975), is again illuminating. The APA at least attempts to shield from bias Administrative Law Judges who, like university administrators, must adjudicate individual claims against the agencies which employ them. The Act provides that ALJs "shall be assigned to cases in rotation so far as practicable, and may not perform duties inconsistent with their duties and responsibilities as administrative law judges" (5 U.S.C.A. § 3105 (West Supp. 1986)); that ALJs "are entitled to pay prescribed by the Office of Personnel and Management independently of agency recommendations or ratings" (5 U.S.C.A. $\S 5372$ (West 1980)); and that an ALJ may be removed, suspended, or have his pay reduced "only for good cause established and determined by the Merit Systems Protection Board" (5 U.S.C.A. \& 7521 (West 1980)).

62. Several commentators have observed that utilitarian analysis is incompatible with any theory of due process that treats individual dignity as a serious, operative societal value. See Saphire, Specifying Due Process Values: Toward a More Responsive Approach to Procedural Protection, 127 U. PA. L. REv. 111, 155 (1978) ("Aside from its questionable assumption that the societal cost of procedural protection can reliably be predicted, utility theory tends to minimize the value of the less quantifiable factors . . . by setting them off against more easily identifiable and often intuitively more compelling conceptions of public good."); Tribe, Constitutional Calculus: Equal Justice or Economic Efficiency?, 98 HARV. L. REv. 592, 596 (1985):

The inevitable result [of utilitarian policy analysis] is not only that "soft" variables-such as the value of vindicating a fundamental right or preserving human dignity-tend to be ignored or understated, but also that entire problems are reduced to terms that misstate their structure and that ignore the nuances that give these problems their full character.

To illustrate the problem in the context of the university setting, consider these hypotheticals:

- Students protest against a university investing in companies that do business in South Africa. The protests are covered extensively by the local media, including television scenes of student protesters criticizing the conduct of high-ranking university administrators. The president unilaterally suspends 150 students for taking part in the protests. Do the protesters constitute "an ongoing threat of disrupting the academic process"? Or, is the president merely afraid to have his university appear as something less than tranquil?

- At a highly competitive professional school, students steal one another's notes, sabotage each other's work, harass one another, and occasionally assault one another. Finally, one student is seriously injured by another in a fight. The incident draws a great deal of attention from local media and other institutions. The Dean of the school summarily suspends the student he believes to be the offender and then slaps a gag order on the school's employees, supposedly to protect reputations. Is the Dean simply acting responsibly to protect the school community? Or, is he afraid that outside scrutiny, generated by the one incident, will reveal a bad situation he allowed to develop? What if the injured student had previously complained to him about the attacker and the Dean had ignored it? What if the injured student's father is the president of the Alumni Association?

- A student is summarily expelled from a public university without any type of due process proceeding. He sues the President and the Dean for reinstatement, a public apology, and several million dollars in damages. The federal court orders that the student be given the due process hearing he should have had before being expelled. Can the university conduct an impartial hearing, knowing that to lose would expose both the President and the Dean to liability? Could anyone employed by the university be an impartial trier of fact? 
Even without the bias of a pecuniary interest, a university administrator may be prejudiced simply by prior contact with the student or the matter in controversy. ${ }^{63}$ Any time an adjudicator bases his decision on considerations outside the hearing, due process is violated, as there is no way for the defendant to challenge those extraneous considerations. ${ }^{64} \mathrm{~A}$ university administrator not only may have had prior contact with the conflict upon which he is to rule, but also may easily have had a hand in its development-for example through some action of his that caused the conflict or by not adequately discharging his responsibilities and, thus, failing to resolve the conflict at an earlier point. Consequently, dealing fairly with a student-either in deciding whether to charge him or in deciding whether to find him guilty-may require the administrator to disaffirm his own previous judgments.

University disciplinary cases that involve potential suspension or expulsion will almost certainly involve the potential bias of either a pecuniary interest to the university or the administrator, or a significant prior contact on the part of the administrator. The probability of unfair bias from one of these sources is too high to be constitutionally tolerable and, thus, justifies a per se prophylactic rule of separation of functions. ${ }^{65}$ At a mini-

63. In Escobar v. State Univ. of N.Y./College at Old Westbury, 427 F. Supp. 850 (E.D.N.Y. 1977), the student had been formally charged under the college's disciplinary code, had submitted to a hearing, and had been sentenced by the college's Judicial Review Committee. The President of the college learned of the sentence after the fact and, "[b]ased on his own recollection of other events involving the [student]," he unilaterally imposed a harsher sentence-including immediate suspension and eviction from the dorms. Id. at 853 . Additionally, the President conditioned the possibility of reenrollment upon the student submitting to psychiatric evaluation.

64. See In re Murchison, 349 U.S. 133 (1955). Murchison involved a state judge, empowered under state law to sit as a "one-man grand jury" and to compel witnesses to testify before him in secret about possible crimes, who charged two such witnesses with criminal contempt (one for perjury and the other for refusing to answer questions), and then tried and convicted them himself. The Supreme Court found the procedure to be a denial of due process not only because the judge became part of the prosecution and assumed an adversary position, but also because as a judge passing on guilt or innocence, he likely relied upon "his own personal knowledge and impression of what occurred in the grand jury room," an impression that "could not be tested by adequate crossexamination." Id. at 138. The Court decided that "[i]t would be very strange if our system of law permitted a judge to act as a grand jury and then try the very persons accused as a result of his investigations." Id. at 137; see also Morrissey v. Brewer, 408 U.S. 471 (1972) (parole revocation requires evaluation by person other than parole officer who reported violations or recommended rearrest); American Cyanamid Co. v. FTC, 363 F.2d 757 (6th Cir. 1966) (due process requires disqualification of FTC Chairman who had previously investigated controversy before him as Chief Counsel of Senate subcommittee); Amos Treat \& Co. v. SEG, 306 F.2d 260 (D.C. Cir. 1962) (denial of due process for SEC Commissioner to sit on panel adjudicating charge he had investigated before becoming Commissioner).

65. The flexibility of due process should apply to different decisionmaking contexts, not to different cases within a context. The Supreme Court's most successful due process rulings have established rules with general application to similarly situated cases. See, e.g., Goldberg v. Kelly, 397 U.S. 254 (1970) (disparate economic conditions experienced by welfare recipients as class distinguished them from other recipients of governmental benefits and, consequently, due process required evidentiary hearing before termination of benefits); Mathews v. Eldridge, 424 U.S. 319 (1976) (needs of Social Security disability recipients as class not so urgent as to require pretermination hearing). Such contextual rules not only guarantee predictability and uniformity in adjudications, they also reduce the cost 
mum, the adjudicator should have no responsibility for university fundraising, have some type of insulating job security such as tenure, have had no part in the investigation of the matter in question, and have had no prior experience with either the matter or the student.

\section{III. "Some Kind of Hearing": The Bias Spreads}

The problem facing a university should be how to insulate the hearing, and especially the decisionmaker, from the influence of tainted officials. Rather than even address that problem, however, most universities go the other way. They fight to give students fewer, not more, procedural safeguards.

\section{A. Why Bias Reaches the Decisionmaker}

As a practical matter, significant insulation of the decisionmaker seems impossible. Even universities the size of small towns constitute the smallest of communities. This is especially true of the administration and faculty. Even without the obvious taint of a high-placed administrator appointing particular faculty members to adjudicate, the administrator remains the superior-or, at least, the colleague-of the faculty members.

A similar problem exists with student adjudicators. By the simple fact that the defendant has been charged, the student adjudicators know the administrator's position and, further, they know the influence university officials have over their lives. ${ }^{68}$ Furthermore, students are perhaps even more susceptible to the small community problem. They live together, eat together, and spend their evenings together. Peer pressure is strong and rumors spread quickly, often disseminated in the pages of student publications. For a student decisionmaker to face what can amount to outright coercion by his peers may be too much to ask.

Even if one reaches into the community for impartial decisionmakers, one still encounters difficulty with university influence. Many local people

and unfairness of post-verdict procedural challenges.

Fairness concerns also dictate a per se rule under the Mathews $v$. Eldridge balance. Having a second university employee, such as a tenured professor, sit as the actual decisionmaker is a small procedural burden when weighed against the student's interest in his education and the chance of erroneous deprivation.

66. Students place themselves in the professional world through the recommendations and evaluations of university officials, primarily professors. As recommendations are discretionary, and the Supreme Court has said academic evaluations should rarely be questioned, see supra note 15, a university can punish a student with impunity. One of the charges against Wilson Crook, for example, was that he had lied about having performed experiments with a device called a "microprobe" in preparation of his thesis. Crook asked another graduate student named Don Alexander, who had assisted Crook in performing the experiments in question, to testify on his behalf at the University hearing. Alexander declined to do so. Alexander was still a candidate for his Ph.D. and one of the professors at the University had warned him to "keep a low profile" in the proceedings against Crook. Crook v. Baker, 584 F. Supp. 1531, 1546-47 (1984). 
may have an allegiance to the university, if not as alumni, then at least to the university as a major employer. Many universities attempt to improve "town-gown" relations by asking local business people to serve as lecturers, fellows, or in some other flattering capacity ${ }^{67}$ In sum, too many people in a university town live in the university's shadow. ${ }^{68}$

The next alternative would be to select a decisionmaker from outside the university's sphere of influence, preferably one of stature who would be less susceptible to political pressure. The administrative burden, however, would be great-too great to be practical for a university to shoulder every time it sought to suspend a student for common or obvious transgressions, such as fighting or drunkenness.

\section{B. Why Bias Taints the Rules}

As difficult as it is to insulate the decisionmaker from the influence of biased university officials, currently there is even less possibility of insulating procedural rules from their influence. After Goss v. Lopez, the Supreme Court failed to detail explicitly what procedures are due students before expulsion, deciding instead to allow universities "flexibility." Consequently, specific rules were left to be drawn by the very officials against whom they should have afforded protection. The rules they drew, predictably, afforded students very little protection —and universities today fight to keep from giving students more.

As an example, consider the question of what should comprise adequate notice for a student disciplinary hearing. Constitutionally adequate notice should inform someone not just of the pendency of the action, but of the evidence against him and the rules of the forum, so that he "can choose for himself whether to appear or default, acquiesce or contest." "Yo Yet, con-

67. If town-gown relations are poor instead of good, a similar problem of bias may exist.

68. In 1986, for example, there were 141,300 people employed in Washtenaw County, Michigan. Of those, 47,756 were employed either by the University of Michigan or by the University of Michigan Medical Center, easily making it the County's largest employer. MESC Civilian Labor Force and Employment Statistics (1986) (provided by Washtenaw County Metropolitan Planning Commission; on file with author). Similarly, the University of North Carolina, Indiana Univerity, and Pennsylvania State University were all the largest employers in their communities. Demographic and Employment Statistics (1986) (provided by Chapel Hill-Carrboro Chamber of Commerce; on file with author) (University of North Carolina largest employer in Orange County); Employer Figures (1986) (provided by Greater Bloomington Chamber of Commerce; on file with author) (Indiana University largest employer in Bloomington); Regional Trends and Forecasts (1987) (provided by Centre Regional Planning Commission; on file with author) (Pennsylvania State University largest employer in Centre County). The University of Washington is the third largest employer not just in the Seattle area, but in the entire state of Washington. 1987-88 Top 100, in Greater SEATTLE Chamber of Commerce, Directory of Major Employers Central Puget Sound Region (1987).

69. Board of Curators, Univ. of Mo. v. Horowitz, 435 U.S. 78, 86 (1978).

70. Mullane v. Central Hanover Bank \& Trust Co., 339 U.S. 306, 314 (1950). The Court went on to say that "when notice is a person's due, process which is a mere gesture is not due process. The means employed must be such as one desirous of actually informing the absentee might reasonably 
sider what major universities have actually provided as "notice": a student at the University of North Carolina received notice on the day of the hearing, and even then it failed to include the specifics of the charges, the identity of her accusers, or any of the evidence against her; ${ }^{71}$ the University of Michigan sent the student a letter raising the matter in question, but failed to make a charge, or specify any of the evidence, the procedures to be used, or even the forum, ${ }^{72}$ and for the University of Kansas, notice consisted of telling the student he was already suspended, without having had an opportunity to be heard or even telling him what evidence supported the charge. ${ }^{73}$

As another example, consider how the University of Rhode Island provides due process to its students. In the fall of 1977, Steven Gabrilowitz, then a senior at U.R.I., was charged by the local police with assault with intent to commit rape on another student. The criminal charge carried a potential penalty of twenty years in prison. Subsequently, Gabrilowitz was charged by the University on the same facts with violating its Community Standards of Behavior. The University charge carried a possible sanction of expulsion. The University decided to hold its disciplinary hearing before Gabrilowitz's criminal trial, ${ }^{74}$ but would not allow Gabrilowitz to have an attorney present during that hearing. Gabrilowitz brought a federal suit against U.R.I., claiming that to deny him counsel during the hearing-and, thus, risk incriminating himself before his trial-was a denial of due process. The United States Court of Appeals for the First Circuit agreed and ruled Gabrilowitz had to be allowed to consult with his attorney during the hearing. ${ }^{78}$

Two years later, the University of Rhode Island was in court again with essentially the same situation. This time three students were charged both criminally and by the University with sexual assault. Although the University admitted that, under the Gabrilowitz ruling, it had to allow the students' attorneys to be present during its disciplinary hearing, it now was in court to keep those attorneys from cross-examining the University's witnesses. While the Rhode Island Superior Court eventually ruled that

adopt to accomplish it." Id. at 315 . Under Mullane's construction, proper notice to a student might be thought to include the elements listed infra Section V.B.2. Certainly, all of those points should be considered by a university before they charge a student just to avoid charging him frivolously. Furthermore, if the university is indeed proceeding in good faith, the efficiency of complete notice serves the best interests of all parties by avoiding mistrials-as opposed to allowing "trial by ambush" if the university is not proceeding in good faith.

71. Jones v. Board of Governors of the Univ. of N.C., 557 F. Supp. 263, 264 (W.D.N.C. 1983).

72. Picozzi v. Sandalow, 623 F. Supp. 1571, 1580 (E.D. Mich. 1986). The District Court's holding that this constituted constitutionally adequate notice was even more startling.

73. Gardenhire v. Chalmers, 326 F. Supp. 1200, 1201 (D. Kan. 1971).

74. As it turned out, Gabrilowitz never was criminally tried. The only witness against him decided to drop the charges and left the state.

75. Gabrilowitz v. Newman, 582 F.2d 100, 107 (1st Cir. 1978). 
the University did not have to allow cross-examination by defense coun$\mathrm{sel}{ }^{76}$ the more important point is that the University of Rhode Island was in court at all. Cross-examination has long been recognized as one of the best methods for determining truth ${ }^{77}$ and a trained trial attorney is the best person to employ that method. ${ }^{78}$ Even if U.R.I. was not obligated to allow cross-examination by defense counsel, and even if such crossexamination potentially could have added hours to the hearing, ${ }^{79}$ those hours seem a small administrative burden to an institution seeking the truth first-especially with a charge as serious as rape. U.R.I. shouldered a much greater administrative burden by contesting the cross-examination issue in court than simply by allowing the cross-examination.

The Jones, Gardenhire, Gabrilowitz, and Boyle cases are not isolated examples. The fact is that most public universities try to short-change their students on procedure. In 1980, Edward J. Golden, the Assistant Dean of Students at the University of Virginia, contacted eighty-three different public institutions and asked them what procedural protections were afforded students who faced disciplinary dismissal. ${ }^{80}$ Of the fiftyeight institutions that provided data on disciplinary procedures, ${ }^{81} 36.2 \%$ did not allow cross-examination by defense-not even by the accused student-and $37.9 \%$ did not allow the student to have legal counsel. ${ }^{82}$ Staggeringly, 55.2\% did not guarantee the student an impartial decisionmaker (in the form of either a hearing officer or a tribunal), $60.3 \%$ did not guarantee the student a right to confront his accusers, $75.9 \%$ did not guarantee the student written findings of fact, and $91.4 \%$ provided students with no assistance of any kind-let alone compulsory process-in getting specific persons to testify at proceedings. ${ }^{83}$ Golden did not inquire as to conviction rates.

The procedural game too many universities in this country play is to give students enough process to fulfill the vague dictates of Goss, but not enough for the student to have a fair opportunity to defend himself-not enough to keep the university, and its officials, from having their way

76. Boyle v. Newman, No. 79-335 (C.A.R.I. June 19, 1980).

77. See MCCORMICK ON EvidENCE \$\$19-32 (2d ed. 1972).

78. See F. Wellman, The Art of Cross Examination (4th ed. 1936).

79. Besides the administrative burden of allowing the hearing to escalate, the University of Rhode Island might have had an interest in protecting student witnesses from the trauma of a pointed cross-examination and a consequent chilling effect on future student witnesses. While legitimate, these concerns pale in comparison to allowing accusations of serious crimes, such as rape, to go untested.

80. Golden, Procedural Due Process for Students at Public Colleges and Universities, 11 J.L. \& EDuc. 337 (1982).

81. The 58 included 28 doctorate-granting institutions, 13 comprehensive universities and colleges, 8 liberal arts colleges, and 9 professional schools. Id. at 348-51.

82. Id. at $345-46$.

83. Id. at $345-47$. 
with him. ${ }^{84}$ That procedural game is not only unconstitutional, it exposes the myth of universities acting objectively towards their students. There's nothing magically collegial about a university; once a student is charged, a full-fledged adversarial relationship exists, and university officials are like everyone else. They play to win. ${ }^{85}$

\section{Unfair Procedures and the Burdens They Create}

Under current law, a student at a public university can find himself exposed to a variety of burdens - the cost of a defense, the proof of a due process violation, the risk of self-incrimination-all because of one arbitrary decision by a university administrator.

For the accused student, the first burden is financial. The defense of a student in a disciplinary proceeding can easily become a full-blown criminal defense, and be just as expensive, ${ }^{86}$ while students may be among the

84. Procedural safeguards, like affirmative defenses, are not created to be loopholes for shysters; they are created to protect the innocent. Given that comparative similarity, the way institutions fight to withhold procedural safeguards calls to mind the words of New Jersey attorney Robert Ansell:

There is something unsatisfying about the position of those who pay lip-service to the soundness of a . . . defense but fear for its application. It is not unlike the uproar that followed the acquittal of John Hinkley in the attempted assassination of President Reagan. What was it that fueled the demands for the abolition of the insanity defense, especially in a context where it must have been apparent to the community-at-large that Hinkley's connection to reality was, at best, tenuous? What was wrong, of course, was that the defense worked.

Responding Brief on Behalf of Defendant at 14, New Jersey v. Michael Tate, 102 N.J. 64, 505 A.2d 941 (1986) (No. A-23,512).

85. Major universities in this country have not been above creating new procedures ex post facto in order to allow them to discipline students. In Crook v. Baker, for example, the University of Michigan arbitrarily decided not to follow its own Graduate School Code of Conduct and Enforcement Procedures. In fact, Virginia Nordby who, at the time of Crook's hearing, had for four years been responsible for drafting codes of conduct and procedures for their enforcement for the various schools of the University, testified that the University of Michigan Graduate School had no procedure for enforcing conduct in place at the time of the Crook matter. However, there had been. Crook v. Baker, 584 F. Supp. 1531, 1538 (E.D. Mich. 1984). In altering the disciplinary procedures, University of Michigan officials, including Nordby, eliminated inter alia all lower, mediatory steps in the disciplinary process and eliminated all student participation on the adjudicatory panel. Id. at 1539.

86. In prosecuting the student in Picozzi v. Sandalow, for example, the University of Michigan admits to having spent approximately $\$ 100,000$. Arbiter at $U-M$ Rules in Favor of Expelled Law School Student, Ann Arbor News, Aug. 26, 1985, at A1, col.1. That figure included the cost of bringing witnesses to Ann Arbor from as far away as St. Louis and Washington, D.C., of hiring two medical expert witnesses and one arson expert witness, and of preparing over thirty 2'x 3' mounted photographs, an artist's rendering of the student's room, and an aerial photograph of the University of Michigan Law School Quadrangle. The student defendant, to rebut the prosecution, had to spend a similar amount.

In the criminal justice system, before a defendant must pay for a full defense, at least two, and perhaps as many as four, different entities must make a finding that he should be prosecuted. Minimally, a prosecutor must decide to proceed against the defendant and a judge must make a finding of probable cause. Additionally, the prosecutor may not have the opportunity to make a decision if the police do not submit the case to him. Finally, either by law or a prosecutor's election, a determination by a grand jury may also be required.

In contrast, due to the melding of functions, see supra notes 50-57 and accompanying text, if a university president, dean, or other official decides a student should be charged, there may be no mechanism to check his decision. On one person's inclination, a student may be forced to decide 
least able to afford attorney's fees ${ }^{87}$ and the other expenses of litigation. ${ }^{88}$ Furthermore, students may face unique costs, such as having to travel a great distance to secure counsel from outside the university's sphere of influence. ${ }^{89}$ Finally, even if the student can somehow muster the resources to defend himself successfully, he must still be left in a position to pay his tuition.

If the university uses unfair procedures in expelling a student, it creates a second, legal burden for him. The burden should lie with the university to prove the student's guilt in a due process hearing before it expels him. Yet, by using unfair procedures, not only can the university avoid its own burden of proof, but also it forces the student to prove a denial of due process in a civil suit. Moreover, now the student must have legal counsel $^{90}$ and overcome several obstacles simply to receive fair process: as a constitutional matter, the student may have difficulty proving his case because the Supreme Court has provided no detailed procedural standard for disciplinary expulsions; ${ }^{91}$ as an evidentiary matter, the student may have difficulty proving the influence of bias given the subtle way it may pervade the university's administration; ${ }^{92}$ and as a financial matter, the stu-

whether to foot the bill for a major defense or give up his college career.

87. As one indication of the unusual financial burden that any public university student shoulders, consider that, in the academic year 1985-86, the average indebtedness for a student following four years at a public college was $\$ 6,685$. J. Hansen, Student LoANS: ARE They OverbuRdening a GENERATION? 8 (1987). Moreover, of students who had outstanding loans, $65.1 \%$ owed $\$ 5,000$ or more. Id.

88. For a brief list of general litigation costs, see F. James \& G. Hazard, Civil Procedure $\S \S 6.3-6.5$ (3rd ed. 1985). Note that contingency fee arrangements only become viable if the student counterclaims against the university for damages arising out of a denial of due process. Even then, the student may have to pay, at the outset, a significant retainer against the lawyer's percentage.

89. In Picozzi, for example, well over a dozen lawyers and law firms in Michigan and Ohio declined to represent the student to avoid being placed in an adversarial position towards the University of Michigan Law School. However, more than the financial cost here is the emotional cost: The student may be left feeling defeated by the simple fact that no one will take his side.

90. Assuming the student has the legal wherewithal even to consider that there might be a legal challenge to the University's authority, without a national constitutional standard, it may be difficult for a student to know whether he should simply submit to the university's rules, or whether he should challenge them. As the law now stands, just evaluating whether to challenge the university's procedures can be sufficiently complex to require legal counsel. If the student does decide to challenge the procedures, he must then determine when to challenge. If he waits until after the hearing to file suit, a court may deem his participation to constitute a waiver. If he files before the hearing and the court finds the procedures adequate, the student bears needless expense and certainly increases the ire of the university.

91. See supra notes 5-14 and accompanying text. Universities can shift the burden of proof to the student because of the Supreme Court's failure to articulate a national procedural standard after Goss. Yet, shifting the burden of proof allows universities to violate the one explicit rule Goss did articulate: It allows a university to suspend a student without due process.

92. See supra notes 58-64 and acompanying text. If university officials do not start out with a bias against a student defendant, they may well develop one after having been forced into court and, possibly, having been sued individually for damages. As these are state institutions, and as one cannot sue the state without its permission, the student's most likely recourse would be a federal action under 42 U.S.C. $§ 1983$ (1981), for a denial of due process and ancillary damages stemming therefrom.

University administrators may seek protection from such claims behind a shield of qualified immu- 
dent may not be able to afford his day in court. A student may well be forced from school simply because he cannot afford to compete with the university's far superior resources. ${ }^{93}$

Special risks, as well as additional financial and emotional burdens, arise for the student accused of an act that, in a criminal forum, would constitute a felony. Now the wrong choice may not just mean expulsion; it may mean criminal conviction, because the student runs the risk of incriminating himself in the university disciplinary hearing. How great a risk of self-incrimination-and, thus, how difficult the student's choices-depends upon where in the criminal process the student is when the university decides to hold its hearing.

The easy cases occur when the student has already been criminally tried and a verdict returned before the university hearing. If the student has been acquitted, the double jeopardy doctrine will shield him from a second criminal prosecution based upon an incriminating disciplinary hearing. ${ }^{94}$ If the student has been convicted, the problem is in large measure moot. ${ }^{98}$ Moreover, on a practical level, having been found guilty beyond a reasonable doubt in a full criminal proceeding, the concern over an erroneous factual finding in the disciplinary hearing dissolves.

The risks become more dramatic where the student has been criminally charged, but not tried, at the time of the university hearing. ${ }^{96}$ Here the

nity. See Harlow v. Fitzgerald, 457 U.S. 800,818 (1982) ("[G]overnment officials performing discretionary functions, generally are shielded from liability for civil damages insofar as their conduct does not violate clearly established statutory or constitutional rights of which a reasonable person would have known."). The test for qualified immunity focuses in large part upon whether the applicable law was clearly established at the time the action occurred. Thus, the Court in Harlow wrote: "If the law was clearly established, the immunity defense ordinarily should fail." Id. Ever since Goss v. Lopez, the law has been well-settled that before a student can suffer even a de minimis suspension, he must be given notice of the charges and evidence against him, and a hearing before an impartial decisionmaker. See supra note 6. However, Supreme Court jurisprudence is not the only well-settled law and, for purposes of defeating a claim of qualified immunity, the body of lower court rulings might be held to put a university administrator on notice that even more elaborate procedures are due. See, e.g., Dixon v. Alabama State Bd. of Educ., 294 F.2d 150, 159 (5th Cir. 1961) (requiring studentdefendant be provided with names of witnesses against him, report of facts to which each witness would testify, be given opportunity to present witnesses or affidavits of witnesses on his own behalf and, if hearing not directly before State Board, results and findings should be presented in report open to student's inspection). In Goss $v$. Lopez, the Supreme Court described Dixon as a "landmark decision." 419 U.S. 565,576 n.8 (1975).

93. The financial burden seems particularly cruel as the logical effect of expulsion is to reduce the student's earning power. See supra note 41 and accompanying text.

94. See, e.g., United States v. Scott, 437 U.S. 82, 91 (1978) ("A judgment of acquittal, whether based on a jury verdict of not guilty or on a ruling by the court that the evidence is insufficient to convict, may not be appealed and terminates the prosecution when a second trial would be necessitated by a reversal.").

95. It is possible that facts might be exposed in the disciplinary hearing which were not exposed in the criminal trial and, thus, could affect the student's criminal sentencing or some pending civil litigation.

96. Several federal courts have already ruled that universities may run such hearings in advance of criminal trials. See Wimmer v. Lehman, 705 F.2d 1402, 1406 (4th Cir. 1983); Gabrilowitz v. Newman, 582 F.2d 100, 104 (1st Cir. 1978); Hart v. Ferris State College, 557 F. Supp. 1379, 1391 
student faces a true Hobson's choice: He can meaningfully defend himself in the disciplinary hearing, potentially incriminating himself ${ }^{97}$ and certainly exposing the strengths and weaknesses of his case to the criminal prosecutor, or-wanting most of all to avoid going to prison-he can decide to give his criminal defense its best chance by not putting on a defense in the disciplinary hearing and, thus, simply allowing himself to be expelled. One thing is certain: No matter how the student proceeds with regard to the disciplinary hearing, he will be criminally tried.

The risks are greatest-or, at least, the most difficult to gauge-where the student has not been criminally charged at the time of the university hearing. How he proceeds here with regard to the hearing may determine whether he is criminally charged. If, to avoid the risk of self-incrimination, the student does not contest the university's charge and simply allows the expulsion, he faces a devastating blow to his career, but may improve his chances of not being criminally charged and, ultimately, imprisoned. If, however, he puts on a vigorous defense in the disciplinary hearing-and, especially, if the defense means he must testify-then he risks providing the basis for a criminal charge.

One ominous variable, impossible for the student to know, is to what extent university and law enforcement officials may have coordinated their actions against him. Certainly, they share an interest in removing a felon from the community. The connection, though, usually runs deeper. Universities almost always enjoy a cooperative relationship with local law enforcement authorities. Virtually all universities, for example, have their own police forces which are deputized members of the local police. ${ }^{88}$ It is

\section{(W.D. Mich. 1983).}

97. A state entity may not in any way penalize a person for exercising his right against selfincrimination. See Lefkowitz v. Turley, 414 U.S. 70 (1973) (holding unconstitutional state statute which provided that, if officer of political party was subpoenaed by grand jury to testify about his conduct in office and refused to testify or waive immunity against criminal prosecution, his term of office would be terminated and he would be disqualified from holding any party or public office for five years); Garrity v. New Jersey, 385 U.S. 493 (1967) (setting aside convictions of police officers who answered incriminating questions only after being told refusal to answer would result in loss of their jobs). Yet, only $22.4 \%$ of the responding institutions in Golden's study, supra note 80 , allowed student defendants to remain silent in disciplinary hearings without a negative inference being drawn-which may indicate how unconstrained by the law universities feel. However, if a student, after conferring with counsel, decides to testify - not because the university has told him he must, but because he thinks he should in order to rebut the university's case-then the student has knowingly waived his right against self-incrimination and the testimony is admissible in a criminal prosecution. See Moran v. Burbine, 106 S. Ct. 1135 (1986) (waiver is valid if suspect's decision not to rely on his rights was uncoerced, if he knew at all times that he could stand mute and request lawyer, and if he was aware of state's intention to use his statements to secure conviction); Rogers v. United States, 340 U.S. 367 (1951) (once incriminating facts have been voluntarily revealed, privilege against selfincrimination cannot be invoked to avoid further disclosure).

98. In a nationwide survey of college and university police forces, 210 of 230 responding public institutions indicated that their police forces have arrest authority derived either from state police, local police or sheriffs, or from state or local statute, or from both. 1985-1986 Survey of the International Association of Campus Law Enforcement Administrators (raw data obtained from Pennsylva- 
common for local, non-university police to keep academic officials apprised of developments in criminal investigations, for the police to make their files available to universities, and for police officers to make themselves available to testify at university disciplinary hearings. ${ }^{90}$ The danger is that, by assisting in university disciplinary proceedings-and, in fact, by encouraging them-local law enforcement authorities have an opportunity to test a student's case, to have him incriminate himself where before he could not be compelled to speak, or even to try to make a case where one could not be made before. ${ }^{100}$

\section{The Balancing Act: Legitimate Interests and Procedural PROTECTIONS}

The primary function of a university is to provide an education to all of its students. The rights of the individual student must, of necessity, be constrained at the point where they infringe upon the educational rights of other students-whether it be in limiting speech so as not to drown out competing ideas, or whether it be in regulating behavior so as to secure the safety of the university community. Moreover, because the university's primary function is education rather than regulation, and because university officials must deal with large numbers of students, those officials must be accorded a degree of discretion. To conduct a full procedural hearing for every alleged act of student misconduct obviously would be too great an administrative burden, making the job of education impossible. Yet, while many university officials do police these legitimate interests in good faith, procedural requirements must be constructed with those who do not act in good faith in mind. Therein lies the procedural challenge: How to

nia State University Department of University Safety; on file with author).

99. Wimmer v. Lehman, 705 F.2d 1402 (4th Cir. 1983); Gabrilowitz v. Newman, 582 F.2d 100 (1st Cir. 1978); Picozzi v. Sandalow, 623 F. Supp. 1571 (E.D. Mich. 1986); Hart v. Ferris State College, 557 F. Supp. 1379 (W.D. Mich. 1983).

100. In Picozzi, the local prosecutor declined to prosecute the student defendant. Complaint at F1, Picozzi v. Sandalow, 623 F. Supp. 1571 (E.D. Mich. 1986) (No. 84-CIV-7406-AA). The prosecutor requested that the police try to convince the student to take a polygraph examination. Id. The request came to the student, not from the police, but from the Dean after the student had already been suspended. Id. at N-1. The Dean informed the student that he would be re-admitted only if he passed a polygraph examination administered by the police or if he submitted to an administrative hearing. The Dean, however, never informed the student of the rules of the hearing, the charges against the student, or the evidence against the student. Moreover, he urged the student to forego the hearing and simply submit to the polygraph. Id. From the point of whether the student would be re-admitted, both the Dean's lack of adequate notice to the student and his belief that a polygraph examination is an adequate substitute for due process are, at best, questionable. Arguably, however, by encouraging the student to submit to a police polygraph examination-indeed, by conditioning the retention of a constitutionally protected interest by the waiver of another constitutional right-the Dean became part of the criminal prosecution. Even if the polygraph results were not admissible in a criminal prosecution, the tactic of using a failed polygraph exam to coax a confession is common police practice. See, e.g., Oregon v. Bradshaw, 462 U.S. 1039 (1983); Wyrick v. Fields, 459 U.S. 42 (1982); United States v. Gillyard, 726 F.2d 1426 (9th Cir. 1984). 
protect the private interest of the student without so burdening university officials with procedures that they cannot effectively discharge their legitimate responsibilities.

The Supreme Court has insisted upon flexibility in procedure, not just out of deference to legitimate academic judgment, but because "[ $t]$ he very nature of due process negates any concept of inflexible procedures universally applicable to every imaginable situation." however, for it allows the university to select procedure after it has selected a culprit. University officials need to know what procedures must be provided and the student needs to know upon what procedure he can rely.

Because of this need for certainty, the proposals below do not provide for a sliding scale. Instead, they provide for three, distinct categories-based upon the severity of the misconduct and of the possible sanction-so that all similarly situated cases will use the same procedures. Thus, both the administrator and the student will know what process is due. ${ }^{102}$ The procedures allow the administrator the greatest amount of discretion where the student has the smallest interest at stake. Realistically, these "Minor Offenses" constitute the bulk of disciplinary situations. However, where the student's interest grows, and implicates at least a property or liberty interest, and potentially his freedom, the student's interests outweigh the burden on the university in following more rigorous procedures. Thus, in those situations-which, in fact, occur infrequently - the administrator is left with little discretion.

The following proposals for disciplinary procedures are meant to be a guide for universities in creating their own, specific rules. Detailed aspects of the proposals are meant to be suggestive only. The key lies in the values embodied in the proposals and, more importantly, the functions they recommend be performed. These functions should ameliorate the problems outlined in this Note.

A. Minor Offenses. Where the potential penalty will have no permanent effect on the student's academic record-and, thus, implicates no

101. Cafeteria Workers v. McElroy, 367 U.S. 886, 895 (1961) (exclusion of cook from Naval Gun Factory, without notice or hearing, for failure to meet security requirements not violative of due process).

102. Rules offer no protection, however, if the university can simply wish them away. Therefore, a university should not be allowed to charge, prosecute, or discipline a student under a rule which had not been published prior to the student's registration for that academic year.

To guard against a university unfairly shifting the burden of litigation onto the student through use of inadequate procedures, per se rules for costs and liability should be adopted. For example, if the university in any way deviates from its published procedures and the student consequently brings suit to challenge that deviation, the university should reimburse any expenses the student may incur in doing so-whether the change in procedure is found by the court to comply with due process or not. If the deviation is found not to comply with due process, the university officials named in the suit should be held per se liable for punitive damages. 
property or liberty interests-the Disciplinary Administrator (the university official responsible for instigating charges) need only provide the student with an opportunity to discuss the matter in an informal setting.

B. Major Offenses. Where the potential penalty does involve a permanent mark on the student's record-and, thus, does implicate property and liberty interests-the student should be provided with a full array of procedural safeguards.

1. The Charging Process. At a minimum, the procedures should provide for an Investigations Committee, or some mechanism like a Grand Jury, to make a finding of probable cause. It should consist both of tenured faculty serving on a rotating basis, ${ }^{103}$ and of students elected by the entire student body. ${ }^{104}$

If the Disciplinary Administrator believes that reasons exist for a student to be charged with a Major Offense, he should submit those reasons in writing to the Investigations Committee, along with a request that the Committee issue a formal charge against the student. The student should receive a copy of the written request.

Upon receiving a request for a student to be charged, the Committee should discreetly investigate the matter however it deems appropriate. It should, though, keep the subject of the investigation confidential. Its deliberations and investigations should especially be kept confidential from the Disciplinary Administrator until it reaches a decision. It should, however, provide the defendant student with an opportunity to recommend, in writing, areas of investigation. ${ }^{105}$

The Committee should inform both the Disciplinary Administrator and the student, in writing, of its decision. If it finds cause for proceeding against the student, it should specify the offenses with which the Disciplinary Administrator may charge the student.

2. Notice. If the Disciplinary Administrator decides to proceed, he should issue written notice to the student. Proper notice would inform the student of (1) the precise charges lodged against him, (2) the name(s) of the person(s) accusing him, ${ }^{108}$ (3) the specific regulations under which he

103. Rotating faculty on the Investigations Committee serves three functions: first, it hedges against biased faculty members intentionally being kept on the Committee; second, it guards against the development of a "pro-conviction" attitude from having filled a prosecutorial role for too long; third, it requires many faculty members to be exposed to the students' views on the process.

104. If one purpose of education is to teach the "fundamental values necessary to the maintenance of a democratic political system," Ambach v. Norwick, 441 U.S. 68, 77 (1979), then it makes sense for students to learn that protection of their individual rights against a greater utilitarian "good" requires responsible participation in elections.

105. There may be an equally likely suspect who has been overlooked, some other exculpatory evidence, or a simple explanation for what appears to be misconduct. In any event, it serves efficiency for those facts to be aired in the preliminary stages rather than waiting for a full procedural hearing which may, in fact, be unnecessary.

106. Identifying the accuser may expose him to peer pressure or even outright intimidation. Yet, a 
is being charged, (4) the identity of the prosecuting authority, (5) the forum in which the prosecution will take place, (6) the date and place of the hearing, (7) the names of the witnesses testifying against him, (8) a summary of their testimony, (9) a statement of his rights at the forthcoming hearing, (10) the possible sanctions he faces, and (11) his right to appeal any adverse decision. ${ }^{107}$ Additionally, the university should have an ongoing duty to disclose to the student any evidence that tends to negate his guilt. ${ }^{108}$ The notice should be given in a timely fashion. Reasonable postponements of the hearing should be granted automatically to the student as needed for him to secure counsel and to prepare an adequate defense.

3. Intermediate Steps. Before a formal hearing takes place, a student should, at his option, be given an opportunity to discuss the matter in an informal setting with the Disciplinary Administrator in order to achieve a resolution. To promote a full exchange, the contents of the discussions should not be used by either side in the subsequent disciplinary hearings. ${ }^{109}$

A hearing should take place before even a de minimis suspension. ${ }^{110}$ Suspension may take place prior to a hearing only in cases where the

student defendant must, at some point, have the opportunity to confront his accusers and, more, that right to confrontation may be impoverished by a lack of discovery. See Proposed Amendments to Federal Rules of Criminal Procedure: Hearings Before the Subcomm. on Criminal Justice of the House Comm. on the Judiciary, 93d Cong., 2d Sess. 91 (1974) (Statement of Dean Pye):

The cross-examiner has many weapons at his disposal: the development of inconsistencies in the witness' testimony, the establishment of contradictions between the testimony of the witness and the testimony of others, and the impeachment of the witness through the use of prior inconsistent statements, proof of bias, or proof of prior convictions. Effective cross-examination without broad discovery is frequently impossible except in the unusual case where the defendant is sufficiently wealthy to hire private investigators. It is extremely difficult to develop inconsistencies or to effectively impeach any witness whose identity is unknown until he is sworn or until his name is divulged in voir dire.

107. All of the points of notice included here are either procedural decisions that should already have been made and published, scheduling decisions, or matters which the university should have fully explored before deciding to charge the student (e.g., who are the witnesses and what they will say). Having already made those determinations, the administrator need only draft a letter. In exchange, such complete notice prevents claims of mistrial from errors of surprise and, consequently, prevents needless litigation. In sum, besides being just plain fair, it is procedurally efficient.

108. As with any prosecutorial authority, university officials have a duty not just to convict the student as advocates, but to facilitate justice. $C f$. MOdel Code of Professional Responsibility EC 7-13 (1986); Model. Rules of Professional Conduct Rule 3.8 (1986).

109. Cf. FED. R. EvID. 408 ("Evidence of conduct or statements made in compromise negotiations is . . . not admissible."); FED. R. EvID. 410 (holding as inadmissible "any statement made in the course of plea discussions with an attorney for the prosecuting authority which do not result in a plea of guilty or which result in a plea of guilty later withdrawn").

110. What constitutes a de minimis suspension in the university context has never been defined. The only guide comes from Justice White's statement in Goss $v$. Lopez that a ten-day suspension for public high school students was not de minimis. 419 U.S. 565, 576 (1975). This Note takes the position that any suspension that significantly disrupts a student's studies, or in any way is likely to label him as being disciplined to his classmates, is not de minimis. This Note suggests, therefore, a threshold of any suspension lasting more than one full day on which classes meet or any exclusion from school dormitories. 
student's presence presents an imminent danger of bodily harm. ${ }^{11}$ Whenever a suspension takes place prior to a hearing, the hearing must be provided to the student as soon thereafter as practicable.

4. The Hearing. The hearing should take place before a faculty Hearing Officer and a student jury. The Hearing Officer should be selected by the Investigations Committee. ${ }^{112}$ The Hearing Officer should not be someone sitting on the Investigations Committee, should not have had any previous contact with the matter in controversy, should have no pecuniary interest in the matter, and should not be the Disciplinary Administrator. Student jury members, including alternates, should be elected in the spring to serve in all disciplinary hearings in the following academic year. ${ }^{113}$ The student defendant and the Disciplinary Administrator should each have peremptory challenges of jurors. ${ }^{114}$

A proper hearing should (1) consider only the charges and evidence of which the student has formal notice, (2) be open or closed to the public according to the student defendant's choice, (3) allow the student the assistance of counsel, (4) require witnesses to testify under oath, ${ }^{115}$ (5) provide the student with a chance to confront and cross-examine his accusers, (6) provide the student with an opportunity to present evidence and witnesses on his own behalf, (7) not require a student to testify against himself and not allow any adverse inference to be drawn from the student's silence, (8) provide the student with compulsory process over people, objects and documents within the university community, except those otherwise covered by privileges of confidentiality under law, ${ }^{118}$ (9) require the university to

111. Judgments of "imminent danger" require immediate action and, thus, are best left to the discretion of the Disciplinary Administrator. The decision, however, should be reviewed as soon as is practicable by the Investigations Committee, which should have the final decision.

No Disciplinary Administrator should be liable for having suspended a student immediately under a belief of imminent danger; liability should lie, however, against any Disciplinary Administrator who unreasonably delays submitting his decision for review.

112. The Investigations Committee, as a standing independent body representing views of both faculty and students, seems an appropriate selection mechanism for the Hearing Officer. The percentage of votes required for selection of the Hearing Officer should be high enough to require votes of both faculty and student members.

113. The student jury is intended to act as a check against the influence of the Disciplinary Administrator. Student bias or harshness can be checked by requiring only a small dissent for acquittal and, ultimately, by allowing any penalty imposed to be reduced at the discretion of the Disciplinary Administrator.

114. The problem of prior contact between a juror and some other party at the hearing seems especially likely in the small community of a university. The number of challenges must be limited, though, so as not to exceed the number of available alternate jurors. The challenges are peremptory because of the difficulty in defining what should be a challenge for cause in the university setting.

115. The purpose of an oath is to awaken the conscience of a witness and impress upon him the duty to testify truthfully. See, e.g., United States v. Looper, 419 F.2d 1405, 1407 n.3 (4th Cir. 1969).

116. Compulsory process means that the university will use the full extent of its influence to secure witnesses and documents. No enforcement mechanism, therefore, is necessary to produce university employees and documents in the university's possession. Students should be required to appear at such hearings, upon formal request, as a condition of their enrollment-just as following any other 
prove its charge(s) by clear and convincing evidence, ${ }^{112}$ (10) be recorded and transcribed, and (11) produce a written finding of facts by the jurors. ${ }^{118}$

In the event of acquittal, the student's permanent record should either be expunged of any reference to the matter or have added to it a statement of his acquittal, at the student's option. Additionally, in the event of an acquittal, the university should reimburse the student's reasonable costs.

G. Felony Offenses. Any time the university charges a student with an offense which could form the basis for a criminal felony charge, the procedure accorded a student should be the same as in the case of Major Offenses, with the following additional protections.

If the student has already been criminally charged, the university should not hold its own hearing prior to the criminal trial. If the student decides to postpone the hearing until after the criminal disposition, he should be allowed to withdraw completely from the university community and then return, without prejudice, to face the university adjudication as soon as is practicable. Alternatively, he should be allowed to continue to attend classes under whatever restrictions (e.g., a student escort) the university may impose.

If the student has not been criminally charged, he should also be allowed to withdraw for a reasonable period, until the local law enforcement authorities have disposed of the matter. If he is charged, he should again be allowed to postpone the university adjudication until after the criminal trial. If the case is simply filed inactive, however, the university should be able to require his immediate return to face the university

rule is a condition of enrollment. If, for some reason, a student witness still cannot be compelled to appear, the student defendant should be allowed to argue that fact to the jury.

The purpose of these rules is to minimize the effect of the university's much greater influence on the outcome of the hearing.

117. Courts, universities, and student defendants all seem to agree that the appropriate standard of proof in student disciplinary cases is one of "clear and convincing" evidence. See Long, The Standard of Proof in Student Disciplinary Cases, 12 J. College \& U.L. 71 (1985).

118. Compare the elements of a fair hearing listed by Judge Friendly, supra note 43, at 1279-92: (1) an unbiased tribunal; (2) notice for the proposed action and the grounds asserted for it; (3) opportunity to present reasons why the proposed action action should not be taken; (4) the right to present evidence, including the right to call witnesses; (5) the right to know opposing evidence; (6) a decision based exclusively on the evidence presented; (7) right to counsel; (8) requirement that tribunal prepare a record of the evidence presented; (9) requirement that the tribunal prepare written findings of fact and reasons for its decision. Friendly omits cross-examination on the grounds that it would add delay and the necessity of counsel. Id. at 1285. He intends his elements, however, to apply to the entire spectrum of due process hearings. In contrast, a student facing dismissal faces a more severe deprivation than that faced in many of the settings Friendly contemplates and, consequently, the $\mathrm{Ma}$ thews balance indicates greater process is due. Moreover, as student disciplinary hearings are quasicriminal prosecutions, the verdict may turn more regularly on the credibility of non-government witnesses. Cf. U.S. CoNST. amend. VI (right of confrontation limited to criminal cases). 
charges. ${ }^{119}$ (If someone else is criminally charged, presumably the university will drop its charges.)

The substantive procedures used for a Major Offense should be altered as follows: (1) the Hearing Officer should be someone unconnected with the university-such as a tenured professor from another institution, a practicing attorney, or a professional mediator-and should preside at the university's expense; (2) if the student cannot afford legal counsel, the university should provide an attorney for him;, ${ }^{120}$ (3) a unanimous vote of the jury should be required to convict. ${ }^{121}$

\section{ConClusion}

Clearly, the process that public universities currently provide to students is unacceptable by any standard. The courts, not biased administra-

119. The burden always remains on the university to proceed, however. It should never be allowed to place the student in the position of having to request due process in order to complete his education. In Gardenhire v. Chalmers, 326 F. Supp. 1200 (D. Kan. 1971), the student defendant received notice of suspension and was advised that he had, at his discretion, the right to review by the university governing board constituted to handle disciplinary matters. The district court ruled the student's due process rights had been violated, stating that, "in the light of near unanimous authorities, 'the right of review' (or a hearing only upon request), does not serve to protect the right of the student to fundamental fairness in this type of proceeding. One does not have to be a supplicant for allowance of a constitutional right." Id. at 1204.

120. The Supreme Court has stated that "fundamental fairness" requires appointed counsel for an indigent litigant only when the litigant may be deprived of his physical liberty if he loses. Lassiter v. Department of Social Services, 452 U.S. 18, 24-25 (1980) (Constitution does not require appointment of counsel for indigent parents in parental status termination hearing). If a person has been accused by the state, however, or if counsel is necessary to safeguard some independent constitutional right, see, e.g., Miranda v. Arizona, 384 U.S. 436 (1966), then the Sixth Amendment requires appointed counsel at any critical stage on the path to potential incarceration. United States v. Wade, 388 U.S. 218 (1967) (post-indictment line-up critical stage of prosecution requiring appointment of counsel). The Court in Wade explained that a critical stage is "any stage of the prosecution, formal or informal, in court or out, where counsel's absence might derogate from the accused's right to a fair trial." Id. at 226.

While a student disciplinary hearing is not part of a formal criminal proceeding, it is a place where the state, through its agents, accuses a particular student of a felony. Furthermore, in answering that accusation in a constitutionally mandated hearing, the student may make incriminating statements to be used by the state in a later criminal prosecution. See supra note 97 . Thus, a student disciplinary hearing is consistent with other situations in which the Supreme Court has required appointed counsel. See Maine v. Moulton, 474 U.S. 159 (1985) (Sixth Amendment violated when state obtains incriminating statements by knowingly circumventing accused's right to have counsel present in confrontation between accused and state agent); United States v. Henry, 447 U.S. 264 (1980) (violation of Sixth Amendment for government intentionally to create situation likely to induce defendant to make incriminating statements without assistance of counsel); Coleman v. Alabama, 399 U.S. 1 (1970) (state's preliminary hearing critical stage requiring appointment of counsel); see also United States v. Henry, 447 U.S. at 275-77 (Powell, J., concurring) (emphasizing that case did not involve spontaneous statements or passive listening devices, but rather defendant submitted to "functional equivalent of interrogation").

121. Given the extreme penalties that attend expulsion for a de facto felony, the protection of a unanimous jury verdict balances against the lesser procedural protection of a disciplinary hearing as compared to a criminal trial (a "clear and convincing" standard versus "beyond a reasonable doubt," the greater probability of unfair influence reaching a hearing officer as opposed to a judge, or reaching student jurors as opposed to jurors from the community). 


\section{University Disciplinary Process}

tors, should dictate disciplinary procedures. And if the courts fail to ensure students fair procedure, then the lesson they will teach the nation's youth is that a right to due process is a right to nothing at all. ${ }^{122}$

122. In conclusion, I would like to extend my deepest thanks to Alan Silber, Esq., Dr. Josiah Thompson, Dr. Heinrich von Staden, and Dr. Ramzi W. Saad, none of whom had anything to do with the mechanics of writing this Note, but without any of whom I never would have had the opportunity to write it and, ultimately, the opportunity to practice law. 
